\title{
Environmental Pollution by Heavy Metals in the Aquatic Ecosystems of Egypt
}

\author{
Yahya Al Naggar ${ }^{1}$, Mohamed S Khalil ${ }^{2}$ and Mohamed A Ghorab ${ }^{3,4^{*}}$ \\ ${ }^{1}$ Zoology Department, Faculty of Science, Tanta University, Egypt \\ ${ }^{2}$ Agricultural Research Center (ARC), Central Agricultural Pesticides Laboratory (CAPL), Egypt \\ ${ }^{3}$ National Institute of Oceanography and Fisheries (NIOF), Environmental Toxicology Laboratory, Central Laboratories Unit (CLU), Egypt \\ ${ }^{4}$ Department of Animal Science, Wildife Toxicology Laboratory, Michigan State University, USA
}

Submission: February 15, 2018; Published: April 20, 2018

*Corresponding author: Mohamed A Ghorab, Wildlife Toxicology Laboratory, Department of Animal Science, Michigan State University, East Lansing, MI, USA, Tel: 203-824-3136; Email: ghorabmo@msu.edu

\begin{abstract}
Contamination with heavy metals is one of the most serious problems in the aquatic environments. In Egypt, Environmental pollution with heavy metals is one of the biggest problems that face human being. Metals are natural trace components of the aquatic environment, but their levels have been increased due to industrial wastes, geochemical structure, agricultural and mining activities. There are certain heavy metals such as $\mathrm{As}, \mathrm{Cd}, \mathrm{Cu}, \mathrm{Pb}, \mathrm{Ni}$ and $\mathrm{Zn}$ are common pollutants and came from different natural and anthropogenic sources. Metals are partitioned among the various aquatic environmental compartments (water, suspended solids, sediments and biota) and can occur in dissolved, particulates or complex form. Metals have been reported to affect cellular organelles and induced toxicity \& carcinogenicity. The aim of this review is to provide up to date information about metals pollution status, sources, distribution in seawater, sediments in aquatic biota in Egypt and to explore potential ecological risk index methods for heavy metals in sediments
\end{abstract}

Keywords: eavy metals; Pollution; Marine Environment; Contamination; Toxicity

\section{Introduction}

Pollution is considered as one of the most serious problems that faces human societies in the whole world especially in the developing countries. Though produced by man himself and his activities, it has deleterious effects on human's environments and resources $[1,2]$. So, pollution and its effects are considered as one of man's greatest crimes against himself. Pollutants may cause primary damage, with direct identifiable impact on the environment, or secondary damage in the form of minor perturbations in the delicate balance of the biological food web that are detectable only over long time periods [3-5].

Aquatic habitats, especially the freshwater ecosystems, are more subjected to pollution than other environments, because of water use in industrial processes as well as discharge of effluents from industry and urban development's [6,7]. Most aquatic ecosystems can cope with a certain degree of pollution, but severe pollution is reflected in a change in the fauna and flora of the community, which suffer such pollution. River Nile is the principal freshwater resource for Egypt, meeting nearly all demands for drinking water, irrigation, and industry [8]. Contamination of the river Nile and its tributaries with heavy metals may have devastating effects on the ecological balance of the aquatic environment and the diversity of aquatic organisms. It is well known that the level of heavy metals in the water and sediment of some parts of the river Nile is higher than the limits set by the Egyptian General Authority for Standards and Quality Control [9].

The Egypt's northern Delta Lakes include Lake Edku, Lake Borollus, Lake Manzala, and Lake Mariut. These Lakes are situated on the Mediterranean Coast of the Delta and cover about $6 \%$ of the non-desert surface area of Egypt. The Lakes are an important natural resource for fish production in Egypt. Until 1991, these Lakes have always contributed more than $40 \%$ of the country's total fish production, but at present this has decreased to less than $12.22 \%$ [10]. Tilapia species including Oreochromis niloticus, Oreochromis aureus, Sarotherodon galilaeus and Tilapia zillii ranked first followed by Clarias gariepineus in the fish production of the Lakes. However, pollution with heavy metals has been reported in water, sediment and fish species collected from these lakes [11,12].

The Egyptian coastline extends $3000 \mathrm{~km}$ along the Mediterranean Sea and Red Sea beaches in addition to the Gulf of Suez and Gulf of Aqaba. Unfortunately, most of the Egyptian 
coastal zones along the Mediterranean Sea are subjected to intense discharges of pollutants from numerous anthropogenic activities [13]. Some of the Egyptian coastal areas of (especially in front of the large cities) receive different types of pollution sources [14]. In coastal ecosystem, metals exist in either dissolved state in the water column or get deposited on the sediment bed, depending upon the nature of the chemical species and physicochemical factors like $\mathrm{pH}$, conductivity, salinity and organic matter [15-17]. Following industrialization, unnatural quantities of metals such as $\mathrm{Cd}, \mathrm{Cu}, \mathrm{Pb}, \mathrm{Ni}$ and $\mathrm{Zn}$ have been released, and continue to be released into the aquatic environment through storm water and wastewater discharges.

Heavy metals are of high ecological significance since they are not removed from water as a result of self-purification, but accumulate in reservoirs and enter the food chain [18]. The elevation of metal levels in a reservoir is shown mainly by an increase of their concentrations in the bottom sediment. Accordingly, sediments represent one of the ultimate sinks for heavy metals discharged into the environment $[19,20]$.

\section{Natural and Anthropogenic Sources of Heavy Metals}

Table 1: Potential industrial and agricultural sources for metals in the environment [24].

\begin{tabular}{|c|c|}
\hline Metal & Sources \\
\hline $\mathrm{Fe}$ & Pigments and paints; fuel; refineries; textile. \\
\hline $\mathrm{Mn}$ \& Zn & $\begin{array}{r}\text { Batteries and electrical; pigments and paints; alloys and } \\
\text { solders; pesticides; glass; fertilizers; refiners; fuel. }\end{array}$ \\
\hline $\mathrm{Pb}$ & $\begin{array}{r}\text { Batteries and electrical; pigments and paints; alloys and } \\
\text { solders; pesticides; glass; fertilizer; refiners; fuel; plastic. }\end{array}$ \\
\hline $\mathrm{Cd}$ & $\begin{array}{r}\text { Batteries and electrical; pigments and paints; alloys and } \\
\text { solids; fuel; plastic; fertilizers. }\end{array}$ \\
\hline $\mathrm{Ni}$ & $\begin{array}{r}\text { Batteries and electrical; pigments and paints; alloys and } \\
\text { solids; fuel; catalysts; fertilizers. }\end{array}$ \\
\hline $\mathrm{Cu}$ & $\begin{array}{r}\text { Batteries and electrical; pigments and paints; alloys and } \\
\text { solid; fuel; catalysts; fertilizers; pesticides. }\end{array}$ \\
\hline $\mathrm{Cr}$ & Pigments; fertilizers; textile. \\
\hline
\end{tabular}

Heavy metals enter the aquatic ecosystem from both natural and anthropogenic sources. Entry may be as a result of direct discharges into both fresh and marine ecosystems or through indirect routes such as dry and wet deposition and land run-off [21]. Important natural sources are volcanic activity, continental weathering and forest fires. The contribution from volcanoes may occur as large but sporadic emissions due to explosive volcanic activity or as other low continuous emissions, including geothermal activity and magma degassing [22]. The anthropogenic sources include; mining effluents, industrial effluents, domestic effluents and urban storm-water run-off, atmospheric sources e.g. burning of fossil fuels and petroleum industry activities (Table 1).

Anthropogenic inputs, geochemical structure and mining of metals create potential sources of heavy metals pollution in the aquatic environment. Heavy metals are natural constituents of rocks and soils and enter the environment as a consequence of weathering and erosion [23]. Under certain environmental conditions, heavy metals may accumulate to a toxic concentration and cause ecological damage. Heavy metals pollutants are conservative and often highly toxic to biota. They have been shown to be an important group of toxic contaminants because of their high toxicity and persistence in all aquatic system. As, $\mathrm{Cd}, \mathrm{Cu}, \mathrm{Hg}$, and $\mathrm{Zn}$ are the five metals with most potential impact that enter the environment in elevated concentrations through storm water and wastewater discharges as a consequence of agricultural and industrial activity. $\mathrm{Zn}$ and $\mathrm{Cu}$ are used in small amounts as fertilizers in some soils deficient in these elements, while $\mathrm{As}, \mathrm{Cd}$, and $\mathrm{Hg}$ are constituents of some fungicides also used as an algaecide; and $\mathrm{Cd}$ and $\mathrm{Zn}$ occur as contaminants of phosphatic fertilizers. Because of, the concentration of potentially toxic substances in sea water are extremely low and vary considerably in space and time so that their determination is difficult and the obtained data are of doubtful practical interest.

For most heavy metals, anthropogenic emissions are more than or equal to natural emissions. The combustion of leaded petrol in automobiles, for instance, is responsible for the widespread distribution of lead in the world [24]. As, $\mathrm{Cd}, \mathrm{Cu}$, $\mathrm{Hg}$ and $\mathrm{Zn}$ are five metals with most potential impact that enter the environment in elevated concentrations as a consequence of agricultural activity [25].

\section{Delta and Mediterranean coast of Egypt}

The River Nile from Aswan to El-Kanater Barrage receives wastewater discharge from 124 point sources, of which 67 are agricultural drains and the remainders are industrial sources. The total amount of wastewater discharged into the main stem of River Nile has been estimated to be 2628 million cubic meters per year, of which the industrial wastewater constitutes $15 \%$ [26]. Large parts of the Nile Delta suffer from severe coastal erosion, although adequate protection and mitigation measures have been considered. Most of the coastal lagoons "lakes" are however in crisis, suffering from the excessive discharge of industrial, agricultural and domestic sewage flow [27].

Along the Mediterranean coast of Egypt, there are eight coastal governorates. These are from west to east Matruh, Alexandria, Behaira, Kafr El- Sheikh, Damietta, Daqahliya, Port Said, and North Sinai. The enormous urban population and adjacent agricultural areas, all contribute to the pollution load reaching coastal waters. These derived either directly from coastal cities discharge points; the Rosetta branch of the River Nile, the Mahmudiya and Nubariya irrigation canals, drainage canals discharged directly to the sea, such as "El-Tabia and ElUmmum", or from coastal lagoons "lakes" Maryut, Idku, Burullus and Manzala [28].

Alexandria governorate coastal zone receives a large amount of metal pollution from the principle industries of this region include fertilizers, agrochemicals, pulp, paper, power plant, food processing, detergents, fibres, dyestuffs, textile, and building 
materials where, the daily average industrial discharge amounts to 30,000 and $128-261,000 \mathrm{~m}^{3}$ per day domestic sewage and 1-2 million cubic meters per day of agricultural wastes [29]. Rashid, El-Gamil, Damietta and Port Said are exposed to agricultural drains contaminated with hazardous industrial wastes, domestic sewage, organic matter, fertilizers and pesticides, in addition to oil pollution from ships and oil terminal as in Port Said and Damietta [29].

\section{Red Sea of Egypt}

The Aqaba Gulf is a large semi-closed basin of Red Sea. Egypt, Israel, Jordan, and Saudi Arabia have coastlines on the Gulf. Nowadays, the Gulf is highly affected by urban and industrial pollution [30,31], shipping and port activities [32], as well as tourism [33]. Moreover, landbased operations, including clinker production and fertilizer manufacture as well as seawater desalinization in Eilat, may also affect the heavy metals' presence (CASE NUMBER: 380). These anthropogenic activities elevated the concentration of some pollutants in the Aqaba Gulf region [34].

Despite different sources of heavy metals, the coastal and marine sediments are considered as the main fate for heavy metals presence in aquatic systems [35]. In sediment, these pollutants can be adsorbed on several compartments like fine sediment $<63 \mu \mathrm{m}$, organic matter and clay minerals because of their large surface area per unit mass and high cation exchange capacity [36]. Thus the differential adsorption of heavy metals in sediments depends on the content of fine grains, organic matter and clay mineral content.

\section{Metals Distribution}

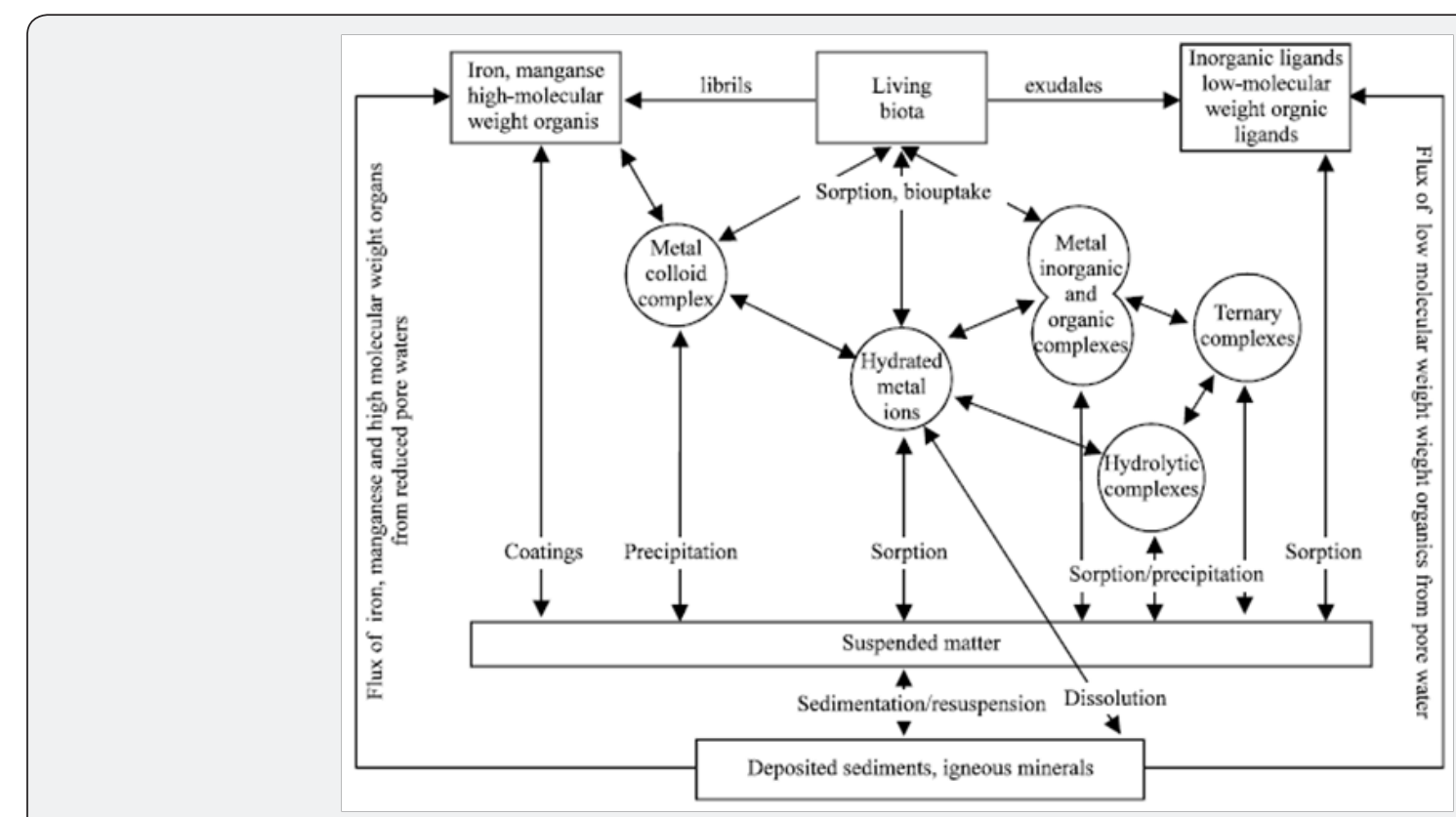

Figure 1: Speciation of metal ions in seawater and the main controlling mechanisms [68].

Metal speciation is the different chemical and physical forms of metals present in the environment (Figure 1). In water this includes all forms of metals, everything from dissolved metal ions or complexes to colloidal forms and metal within or adsorbed on suspended particles. This also includes solids of metals, which can be present in the sediment. The free ion of any metal often is just a small percentage of total amounts of that metal. Each metal species is transported different in the water and sediment and has different toxicological effects on the environment [37]. Comparison of heavy metals distribution with grain size allowed the identification of the area where the sediment fine fraction appears affected by heavy metals from anthropogenic contamination [1]. Two main factors have to be taken into consideration assessing the risk arise from heavy metal-contaminated site; the total amount of the respective heavy metal and chemical binding form of it. Researches on the variables that regulate mobilization and immobilization of toxic heavy metals in aquatic environment are of diverse nature. Most important of these is the relation of toxicity and environmental impacts. However, because our globe contains $» 70 \%$ of water, studies on pollutants that invade the aquatic system are of paramount importance, in particular, metals of cumulative effect (via: $\mathrm{Pb}$ and $\mathrm{Cd}$ ). The natural content of metals in seawater from the geochemical background, the oceans and seas are considered as major receivers of metals coming from several drains as rivers, industrial, agricultural and sewage wastes [38].

\section{Metals in the Aquatic Environment}

Once in the aquatic environment, metals are partitioned among the various aquatic environmental compartments (water, suspended solids, sediments and biota), the metal in the aquatic environment may occur in dissolved, particulates or complex form. The main processes governing distribution 
and partitioning are dilution, dispersion, sedimentation and adsorption/desorption, nonetheless some chemical processes could also occur. Thus speciation under the various soluble forms is regulated by the instability consists of the various complexes and by the physico-chemical properties of the water ( $\mathrm{pH}$, dissolved ions, Eh and temperature [39].

Soils and sediments contain some toxic heavy metals bound within the structural lattice of the crystalline minerals as primary constituent. Metals in this form are un-reactive and only slowly become available over geologic times as the result of natural mineral weathering. The metals fixed within the lattice of minerals are the dominant constituents. Between the readily available and unavailable forms of metals in sediments are a number of chemical forms which are potentially available. Most of metals present in sediments fall into this category. Metals in these potentially available forms may possibly be mobilized to more readily bio-available forms as a consequence of relatively mild physico-chemical changes in sediments and surface waters [23].

Gibbs [20] suggested four groups of heavy metal associations in aquatic solid substances (including suspended matter as well as sediments). They can be characterized by the following bonding processes:

\section{i) Adsorptive bonding;}

ii) Co-precipitation by hydrous iron and manganese oxides;

iii) Complexation by organic molecules and

iv) Incorporation in crystalline minerals. This categorization includes all main types of metal associations in both natural and polluted water systems.

\section{Levels of Heavy Metals in Different Environmental Compartments}

\section{Concentration of Metals in Water}

Saeed and Shaker [11] evaluated the concentrations of heavy metals including ( $\mathrm{Fe}, \mathrm{Zn}, \mathrm{Cu}, \mathrm{Mn}, \mathrm{Cd}$ and $\mathrm{Pb}$ ) in water samples collected from northern Delta Lakes (Edku, Borollus and Manzala). Water from Lake Manzala showed greater concentrations for the most of the metals studied than those reported for Lake Edku and Lake Borollus. Recorded levels above the international permissible limits in water were found in Lake Manzala for ( $\mathrm{Fe}, \mathrm{Mn}, \mathrm{Cd}$ and $\mathrm{Pb}$ ) and for $(\mathrm{Mn}$ and $\mathrm{Pb}$ ) in Lake Borollus.

Hamed et al [38] studied the impact of land-based activity on the distribution of mercury and tin in surface seawater samples from the Egyptian Mediterranean beach during May 2010. The authors found that Nile Delta, Port Said and Alexandria beaches, which are the most industrialized areas in the Egyptian Mediterranean Sea, showed high levels of mercury in water compared to other studied sites. Alexandria beach showed the absolute greatest concentration of tin in water $(1.23 \mathrm{lg} / \mathrm{l})$, while the least concentration was recorded at Port Said area $[0.23$ $\lg / 1)$.

Heavy metals concentrations; $\mathrm{Fe}, \mathrm{Cu}, \mathrm{Cd}, \mathrm{Pb}, \mathrm{Zn}, \mathrm{Cr}, \mathrm{Mn}, \mathrm{Hg}$ and $\mathrm{Ni}$ were determined in water collected from six areas at Assiut Governorate on river Nile, Egypt [40]. The results revealed that $\mathrm{Zn}, \mathrm{Cu}$ and $\mathrm{Fe}$ concentrations were the highest in water followed by $\mathrm{Mn}, \mathrm{Cr}, \mathrm{Pb}, \mathrm{Cd}, \mathrm{Ni}$ and $\mathrm{Hg}$ in areas under investigation.

Ghani [4] assessed the pollution status of Marsa Matrouh Beaches, North West coast of Egypt by estimating levels of V, $\mathrm{Al}, \mathrm{Sn}, \mathrm{As}$, and Se in seawater. Health risk assessment was also concerned. The decreasing trend of metals was observed in water as $\mathrm{Al}>\mathrm{Sn}>\mathrm{As}>\mathrm{V}>\mathrm{Se}$. The levels of dissolved V, Se and as were lower than the typical natural trace element concentration of seawater while, Al surpassed. Dissolved Sn concentration was higher than the background concentration $(0.01 \mathrm{lg} / \mathrm{l})$ but it is still lower than the toxic concentration for organisms.

Sharaf \& Shehata [41] assessed the concentration of heavy metals in water samples collected from two sites (Temsah Lake and Suez Canal, Egypt) represent polluted and unpolluted sites respectively. The results showed that, the levels of the heavy metals ( $\mathrm{Pb}, \mathrm{Cd}, \mathrm{Co}, \mathrm{Mg}$ and $\mathrm{Zn}$ ) in the polluted area have reached harmful limits recorded globally.

\section{Concentration of Metals in Sediment}

Heavy metal (Fe, Mn, Zn, Ni, Co, Cr, Cu, and $\mathrm{Cd}$ ) distribution and concentration in the sediments of the Egyptian coast of Aqaba Gulf have been assessed [34]. Obtained results found large heavy metals fluctuations along the studied area. Moreover, highly significant correlations among $\mathrm{Fe}, \mathrm{Cu}, \mathrm{Ni}$, and Co heavy metals and their similar lithogenic origin beside their input sources were pointed out. Cd was the only metal that showed moderate pollution for Geoaccumulation index (Igeo) as well as it exceeded the primary and the secondary criteria of China State Bureau of Quality and Technical Supervision CSBTS and the threshold effect level of the Canadian guidelines (TEL).

In sediment samples collected from northern Delta Lakes (Edku, Borollus and Manzala), Mn (in Lake Edku) and Cd (in Lake Manzala) recorded higher values than the sediment quality guidelines [11]. Surficial sediment samples have been collected from the Egyptian Mediterranean beach during May 2010 to study the impact of land-based activity on the distribution of $\mathrm{Hg}$ and $\mathrm{Sn}$ [38]. The highest mean value of $\mathrm{Hg}$ in sediments $(14.938 \mathrm{ng} / \mathrm{g})$ was found in Sinai Beach and Sn (1.414 lg/g) was at Alexandria beach. While, in sediments samples collected from six areas at Assiut Governorate on river Nile, Egypt, the order of accumulation was $\mathrm{Fe}>\mathrm{Zn}>\mathrm{Mn}>\mathrm{Cu}>\mathrm{Ni}>\mathrm{Pb}>\mathrm{Cd}>\mathrm{Cr}>\mathrm{Hg}$ [40].

The pollution level with certain heavy metals (Fe, Mn, Zn, $\mathrm{Cr}, \mathrm{Ni}, \mathrm{Pb}, \mathrm{Cu}$, and $\mathrm{Cd}$ ) in sandy sediment samples collected from eight sites along the Egyptian Red Sea coast have been evaluated [14]. The results of the partitioning study showed that the average concentrations of the heavy metals analyzed in 
investigated sediment exhibited the following decreasing order $\mathrm{Fe}>\mathrm{Mn}>\mathrm{Zn}>\mathrm{Cr}>\mathrm{Ni}>\mathrm{Pb}>\mathrm{Cu}>\mathrm{Cd}$.

Ghani [4] assessed the pollution level in Marsa Matrouh Beaches, North West coast of Egypt by estimating levels of $\mathrm{V}$, $\mathrm{Al}, \mathrm{Sn}, \mathrm{As}$, and Se in sediments samples. Pollution load index (PLI) recorded values $>1$ indicate progressive deterioration of the sediment quality. Enrichment factor (EF), contamination factor (CF) and geoaccumulation index (Igeo) demonstrated that most of the sediment samples were moderately to heavily contaminated by Sn which surpassed the threshold limit value (TLV).

\section{Concentration of Metals in Aquatic Fauna}

The bioaccumulation of heavy metals including ( $\mathrm{Fe}, \mathrm{Zn}, \mathrm{Cu}$, $\mathrm{Mn}, \mathrm{Cd}$ and $\mathrm{Pb}$ ) in Nile tilapia (Oreochromis niloticus) organs (muscle, gills and liver) collected from northern Delta Lakes (Edku, Borollus and Manzala) have been evaluated [11]. Gills and Liver of 0 . niloticus contained the highest concentration of the heavy metals detected. The edible part of O. niloticus showed higher levels of $\mathrm{Cd}$ (in Lake Edku and Manzala) and $\mathrm{Pb}$ (in Lake Manzala).

The concentrations of $\mathrm{Fe}, \mathrm{Mn}, \mathrm{Zn}, \mathrm{Cu}, \mathrm{Pb}$ and $\mathrm{Cd}$ in the soft tissues of the bivalve (Donax trunculus) in the Egyptian coastal waters along the Mediterranean Sea, were determined by El-Serehy et al [42]. Obtained results revealed that the concentrations of $\mathrm{Cd}$ and $\mathrm{Pb}$ in the soft tissues of the edible bivalve $D$. trunculus were above the maximum acceptable concentrations for human consumption proposed by FAO/ WHO, EU. Moreover, estimation of concentration factor (Cf) for the studied metals in the soft tissues of the edible bivalve $D$. trunculus recorded high accumulation rates of $\mathrm{Cd}$ and $\mathrm{Cu}$.

Heavy metals concentrations; iron (Fe), copper $(\mathrm{Cu})$, cadmium (Cd), lead ( $\mathrm{Pb})$, zinc ( $\mathrm{Zn})$, chromium (Cr), manganese $(\mathrm{Mn})$, mercury $(\mathrm{Hg})$ and nickel $(\mathrm{Ni})$ were determined in fish muscles of Clarias gariepinus collected from six areas at Assiut Governorate on river Nile, Egypt by Omar [40]. The results revealed that $\mathrm{Zn}, \mathrm{Cu}$ and $\mathrm{Fe}$ concentrations were the highest in muscles, followed by $\mathrm{Mn}, \mathrm{Cr}, \mathrm{Pb}, \mathrm{Cd}, \mathrm{Ni}$ and $\mathrm{Hg}$. While metal bioaccumulation in the muscles of the eight fish species collected by Ghani [4] from Marsa Matrouh Beaches, North West coast of Egypt was in the decreasing order of $\mathrm{Al}>\mathrm{Sn}>\mathrm{V}>\mathrm{Se}$, while As was not detected in all species. Calculated metal pollution indices (MPI) were lower than 1 except in Saurida undosquamis with 1.43 indicating that it is safe for human consumption.

Sharaf \& Shehata [41] assessed the concentration of heavy metals in tissues of the snail cyclope neritea from two sites of the study area (Temsah lake and Suez canal) represent polluted and unpolluted sites respectively. Lead in tissue of the snail reached 7.93 ppm while Cadmium and cobalt reached 3.08 ppm and $10.36 \mathrm{ppm}$ respectively. Meanwhile Magnesium and Zinc concentrations reached $12.6 \mathrm{ppm}$ and $12.60 \mathrm{ppm}$ respectively. The results showed that, the levels of the heavy metals $(\mathrm{Pb}, \mathrm{Cd}$,
Co, $\mathrm{Mg}$ and $\mathrm{Zn}$ ) in the polluted area have reached harmful limits recorded globally.

\section{Ecological Risk Assessment of Heavy Metals}

The assessment of the potential risk of heavy metals contamination was proposed as a diagnostic tool for water pollution control purposes as a result of the increasing content of heavy metals in sediments and their subsequent release into the water, which could threaten ecological health. Many methodologies have been developed to assess ecological risks of heavy metals. However, most of them are suitable only for ecological assessment of a single contaminant (e.g., Geoaccumulation index method and Enrichment factor). In reality, many kinds of heavy metals usually accumulate simultaneously and cause combined pollution. Hakanson [43] developed the potential ecological risk index, which introduced a toxic response factor for a given substance and thus can be used to evaluate the combined pollution risk to an ecological system [44]. On the other hand, mean Sediment Quality Guidelines (SQG) quotient (mSQGQs) has been developed for assessing the potential effects of contaminant mixtures in sediments. Mean SQGQ have been calculated most frequently with SQGs derived with empirical approaches, such as the effects-range-low (ERM), probable effect level (PEL) values, in which measures of adverse effects were associate with, but not necessarily caused by specific chemicals.

Contamination factors (CF) and Pollution load Index (PLI) are calculated for heavy metals in sediment by the equation introduced by Hakanson [43]. Individual Contamination factors are calculated based on the following formula:

$$
C_{f}=M_{x} / M b
$$

Where, $\mathrm{M}$ is the concentration of the target metal and $\mathrm{Mb}$ is the concentration of the metal in the selected reference background, Cf is defined according to four categories as follows: $\mathrm{Cf}<1$ low contamination factor $1<\mathrm{Cf}<3$ moderate contamination factor $3<\mathrm{Cf}<6$ considerable contamination factor $\mathrm{Cf}>6$ very high contamination factor.

Then pollution load index (PLI) for each site can be evaluated as indicated Pollution load index (PLI) =

$$
\left(C f_{1} \times C f_{2} \times \ldots \ldots C f_{n}\right)^{1 / n}
$$

Where, $\mathrm{n}$ is the number of metals and CF is the contamination factor. The contamination can be calculated from; The PLI value $>1$ is polluted whereas PLI value $<1$ indicates no pollution $[45,46]$.

Potential ecological risk index method advanced by Swedish scholar Hakanson [43], is an approach to evaluate the heavy metal contamination from the perspective of sedimentology according to the characteristics of heavy metal and its environmental behavior. It not only considers heavy metal level in the soil, but also associates ecological and environmental 
effects with toxicology, and evaluates pollution using comparable and equivalent property index grading method [47]. According to this method, the potential ecological risk coefficient $\mathrm{E}_{\mathrm{r}}^{\mathrm{i}}$ of a single element and the potential ecological risk index RI of the multielement can be computed via the following equations:

$$
\begin{aligned}
C_{f}^{i} & =C_{s}^{i} / C_{n}^{i} \\
E_{r}^{i} & =T_{r}^{i} \times C_{f}^{i} \\
R I & =\sum_{i=1}^{n} E_{r}^{i}
\end{aligned}
$$

where $C_{s}^{i}$ is the pollution coefficient of a single element of " $i$ "; $C_{s}^{i}$ is the measured level of sedimentary heavy metal; $T_{r}^{i} \quad T_{r}^{i}$ is the background level of sedimentary heavy metal; $C^{i}$ is the toxic response factor for the given element of " $i$ ", which accounts for the toxic requirement and the sensitivity requirement.

Twenty surficial sediment samples from different selected stations along the Egyptian Mediterranean Sea were collected to determine the status of heavy metals distribution and their ecological risk assessment in the studied area [28]. The results revealed that Fe had the highest mean value (243-38045 $\mathrm{ggg}^{-1}$ ) followed by $\mathrm{Mn}\left(17-1086 \mu \mathrm{gg}^{-1}\right)$, and a lower concentrations were found for Co (0.43-26.39 $\left.\mathrm{gg}^{-1}\right)$ and Cd (0.04-0.47 $\left.\mu \mathrm{gg}^{-1}\right)$. Risk assessment showed that $\mathrm{Cd}$ had the highest ecological risk ( $\mathrm{Er}=21.52)$, followed by $\mathrm{Pb}(\mathrm{Er}=3.01)$, while $\mathrm{Zn}$ had the lowest risk $(\mathrm{Er}=0.23)$. Both the ecotoxicological index method and the potential ecological risk index (RI) suggested that the combined ecological risk of the studied metals was low.

\section{Toxicity of Heavy Metals}

In biological systems, heavy metals have been reported to affect cellular organelles and components such as cell membrane, mitochondrial, lysosome, endoplasmic reticulum, nuclei, and some enzymes involved in metabolism, detoxification, and damage repair [48]. Metal ions have been found to interact with cell components such as DNA and nuclear proteins, causing DNA damage and conformational changes that may lead to cell cycle modulation, carcinogenesis or apoptosis [49,50]. Several studies have demonstrated that reactive oxygen species (ROS) production and oxidative stress play a key role in the toxicity and carcinogenicity of metals such as arsenic [51,52], cadmium [53], chromium [54], lead [51,55], and mercury [56]. Because of their high degree of toxicity, these five elements rank among the priority metals that are of great public health significance. They are all systemic toxicants that are known to induce multiple organ damage, even at lower levels of exposure. According to the United States Environmental Protection Agency (U.S. EPA), and the International Agency for Research on Cancer (IARC), these metals are also classified as either "known" or "probable" human carcinogens based on epidemiological and experimental studies showing an association between exposure and cancer incidence in humans and animals.
Heavy metal-induced toxicity and carcinogenicity involves many mechanistic aspects, some of which are not clearly elucidated or understood. However, each metal is known to have unique features and physic-chemical properties that confer to its specific toxicological mechanisms of action. The entrance of certain metals into the nucleus can enhance the synthesis of RNA that codes for metallothioneins. Metallothieneins (MT) are peptides found mainly in the cytosol, lysosomes and in the nucleus, low molecular weight peptides, high in the amino acid cysteine which contains a thiol group (-SH). The thiol group enables MTs to bind heavy metals. Metallothioneins can be induced by essential and non-essential metals in aquatic organisms (mollusks, crustaceans). The MT induction is leading to changes in several biochemical processes that have the potential to be used as biomarkers of exposure and evaluation of pollution in the marine environment [57].

Marine and estuarine species species commonly used for toxicity testing are: rotifers (Brachionus plicatilis), crustaceans copecods (Acartia tonsa), brine shrimps (Artemia salina), mysids (Mysodopsis bahia), bivalves oysters and mussels (Crassosrea gigas, Mytlus edulis or Mytilus galloprovincialis). These marine species are selected on the basis of their availability at low cost, ease of handling in laboratory tests and ecological importance. These marine species are generally supported by the American Society for Testing and Material (ASTM), the U.S. Environmental Protection Agency and International Organization for Stardardisation (ISO) (American Society for Testing and Materials [58,59].

Toxicological studies dealing with heavy metal pollution in aquatic organisms must take into account the interactions among metals that may influence uptake, accumulation and toxicity. Some interactions are antagonistic, such as between mercury and selenium. The toxicity of $\mathrm{Hg}$ is ameliorated by Se in vertebrates. Cadmium and selenium also show interactions $[61,62]$. Studies with heavy metals found interactions of iron (Fe) with mercury (Hg) in the bivalve Mercenaria mercenaria. Low concentrations of Se reduce $\mathrm{Hg}$ uptake in Mytilus edulis $[42,63]$. Copper $(\mathrm{Cu})$ and Manganese $(\mathrm{Mg})$ interactions may have special significance regarding phytoplankton growth [64].

\section{Conclusion}

There are many mechanisms for preventing pollution and mitigating long-term adverse effects. Thus, national legislation and international conventions provide considerable protection from both land- and sea-based sources of pollution. Economic forces can be used to control pollution, either via governmental intervention in the form of taxation or through corporate environmentalism. The main goal of toxicological and ecotoxicological studies is to ensure that heavy metal pollution from anthropogenic pollution do not give rise to adverse effects on living organisms. Ultimately, these studies must focus on measuring levels of pollution that may induce irreversible ecological changes to aquatic ecosystems. Ecotoxicological 
studies with heavy metal pollution must consider the differences in bioavailability among aquatic organisms. The physiological state (e.g. nutritional state) of the aquatic organism has been shown to have a very marked influence on the uptake, distribution and adverse effects of heavy metals. Similarly, environmental factors, such as salinity, oxygen and temperature, may influence permeability and urinary excretion rates of heavy metals in aquatic organisms.

\section{References}

1. Leoni L, Sartori, F (1996) Heavy metals and arsenic in sediments from the continental shelf of the Northern Tyrrhenian/Eastern Ligurian Seas. Marine environmental research 41(1): 73-98.

2. Mendil D, Uluözlu ÖD (2007) Determination of trace metal levels in sediment and five fish species from lakes in Tokat, Turkey', Food Chemistry 101(2): 739-745.

3. Al Naggar Y, Naiem E, Mona M, Giesy J, Seif A (2014) Metals in agricultural soils and plants in Egypt. Toxicological \& Environmental Chemistry 96(5): 730-742.

4. Ghani SAA (2015) Trace metals in seawater, sediments and some fish species from Marsa Matrouh Beaches in north-western Mediterranean coast, Egypt. The Egyptian Journal of Aquatic Research 41(2): 145-154.

5. Sharma YC (2012) A Guide to the Economic Removal of Metals from Aqueous Solutions. Hoboken, NJ: John Wiley \& Sons, USA.

6. Demirak A, Yilmaz F, Levent Tuna A, Ozdemir N (2006) Heavy metals in water, sediment and tissues of Leuciscus cephalus from a stream in southwestern Turkey. Chemosphere 63(9): 1451-1458.

7. Fernandesa C, Fontainhas Fernandesb A, Peixotoc F, Salgadod MA (2007) Bioaccumulation of heavy metals in Liza saliens from the Esmoriz -Paramos coastal lagoon, Portugal. Ecotoxicol Environ Saf 66(3): 426-431.

8. Ibrahim AT (2007) Distribution patterns of some heavy metals and pollution induced changes in some organs of three Nile fish species from assiut, Egypt. Assiut Univ, Egypt, pp.372.

9. Anwar S, Aziza E, El Serafy S, Ibrahim I, Ali E (2001) Accumulation of trace elements in fish at Lake Quaroun as a biomarker of environmental pollution. Journal-Egyptian german society of zoology 36: 443-462.

10. GAFRD (2006) General Authority for Fishery Resources Development. Year-Book of fishery statistics in Egypt (1990-2005), Cairo, Egypt.

11. Saeed SM, Shaker IM (2008) Assessment of heavy metals pollution in water and sediments and their effect on Oreochromis niloticus in the northern delta lakes, Egypt. In 8th International Symposium on Tilapia in Aquaculture 2008 pp. 475-490.

12. Zahran MA, El Amier YA, Elnaggar AA, Abd El Azim H, El Alfy MA (2015) Assessment and Distribution of Heavy Metals Pollutants in Manzala Lake, Egypt. Journal of Geoscience and Environment Protection 3: 107-122.

13. Dowidar M (1988) Productivity of the southeastern Mediterranean. Natural and Man-Made Hazards pp. 477-498.
14. Younis AM, Ismail IS, Mohamedein LI, Ahmed SF (2015) spatial variation and environmental risk assessment of heavy metal in the surficial sediments along the Egyptian Red Sea coast. Catrina. The International Journal of Environmental Sciences 10(1): 45-52.

15. Hagan GB, Ofosu FG, Hayford EK, Osae EK, Oduro Afriyie K (2011) Heavy metal contamination and physico-chemical assessment of the Densu River basin in Ghana. Research Journal of Environmental and Earth Sciences 3(4): 385-392.

16. Lim WY, Aris AZ, Zakaria MP (2012) Spatial variability of metals in surface water and sediment in the Langat river and geochemical factors that influence their water-sediment interactions. The Scientific World Journal 2012: 1-14.

17. Praveena SM, Ahmed A, Radojevic M, Abdullah MH, Aris AZ (2008) Heavy metals in mangrove surface sediment of Mengkabong Lagoon, Sabah: Multivariate and Geo-accumulation Index approaches. International Journal of Environmental Research 2(2): 139-148.

18. Loska K, Wiechuła D (2003) Application of principal component analysis for the estimation of source of heavy metal contamination in surface sediments from the Rybnik Reservoir. Chemosphere 51(8): 723-733.

19. Bryan GW, Langston W J (1992) Bioavailability, accumulation and effects of heavy metals in sediments with special reference to United Kingdom estuaries: a review. Environmental pollution 76(2): 89-131.

20. Gibbs RJ (1973) Mechanisms of trace metal transport in rivers. Science 180 (4081): 71-73.

21. Biney C, Amuzu A, Calamari D, Kaba N, Mbome I, et al., (1994) Review of heavy metals in the African aquatic environment. Ecotoxicology and environmental safety 28(2): 134-159.

22. FAO (1992) Committee for Inland Fisheries of Africa Report of the Third Session of the Working Party on Pollution and Fisheries. Accra, Ghana.

23. Förstner U (1987) Metal speciation in solid wastes-factors affecting mobility. Speciation of metals in water, sediment and soil systems. Springer Berlin Heidelberg p. 11-41.

24. Fifield FW, Haines PJ (2000) Environmental analytical chemistry. Wiley-Blackwell, USA.

25. Alloway BJ (2013) Introduction: In Heavy metals in soils. Springer Netherlands, Germany, p. 3-9.

26. Zaki MS, Authman MM, Hammam AMM, Shalaby SI (2014) Aquatic Environmental Pollution in the Egyptian Countryside and Its Effect on Fish Production (Review). Life Science Journal 11(9): 1024-1029.

27. UNEP (1999) Guidelines for Municipal Solid Waste Management: Planning in Small Islands Developing States in the Pacific Region. South Pacific Regional Environment Programme (SPREP) Western Samoa, Apia.

28. Soliman NF, Nasr SM, Okbah MA (2015) Potential ecological risk of heavy metals in sediments from the Mediterranean coast, Egypt. Journal of Environmental Health Science and Engineering 13: 70. 
29. El Nemr AM, Sikaily AE, Khaled A (2007) Total and leachable heavy metals in muddy and sandy sediments of Egyptian coast along Mediterranean Sea. Environmental monitoring and assessment 129113): 151-168.

30. Walker DI, Ormond RFG (1982) Coral death from sewage and phosphate pollution at Aqaba, Red Sea', Marine Pollution Bulletin 13(1): 21-25.

31. Abelson A, Shteinman B, Fine M, Kaganovsky S (1999) Mass transport from pollution sources to remote coral reefs in Eilat (Gulf of Aqaba, Red Sea). Marine Pollution Bulletin 38(1): 25-29.

32. Badran M, Foster P (1998) Environmental quality of the Jordanian coastal waters of the Gulf of Aqaba, Red Sea. Aquatic Ecosystem Health \&Management 1(1): 75-89.

33. Hawkins JP, Roberts CN (1994) The growth of coastal tourism in the Red Sea: Present and future effects on coral reefs. Ambio 23(8): 503508 .

34. Youssef DH, El Said GF (2011) Assessment of some heavy metals in surface sediments of the Aqaba Gulf, Egypt. Environ Monit Assess 180(1-4): 229-242.

35. Wang WX (2002) Interactions of trace metals and different marine food chains. Marine Ecology Progress Series 243: 295-309.

36. Larsen O, Davison W, Vamvakopoulos K, Møhlenberg F (2007) Fine Sediment Particles; In Sediment Dynamics and Pollutant Mobility in Rivers. Springer Berlin Heidelberg pp. 305-342.

37. Ahnstrom Z, Parker D (1999) Development and assessment of a sequential extraction procedure for the fractionation of soil cadmium. Soil Science Society of America Journal 63(6): 1650-1658.

38. Hamed MA, Mohamedein LI, El Sawy MA, El Moselhy KM (2013) Mercury and tin contents in water and sediments along the Mediterranean shoreline of Egypt. The Egyptian Journal of Aquatic Research 39(2): 75-81.

39. Namieśnik J, Rabajczyk A (2010) The speciation and physico-chemical forms of metals in surface waters and sediments. Chemical Speciation \& Bioavailability 22(1): 1-24.

40. Omar HEDM (2013) Seasonal variation of heavy metals accumulation in muscles of the African Catfish Clarias gariepinus and in River Nile water and sediments at Assiut Governorate, Egypt. Journal of Biology and Earth Sciences 3: 236-248.

41. Sharaf HM, Shehata AM (2015) Heavy metals and hydrocarbon concentrations in water, sediments and tissue of Cyclope neritea from two sites in Suez Canal, Egypt and histopathological effects. Journal of Environmental Health Science and Engineering 13: 14.

42. Fowler BA, Wolfe DA, Hettler WF (1975) Mercury and iron uptake by cytosomes in mantle epithelial cells of quahog clams (Mercenaria mercenaria) exposed to mercury. Journal of the Fisheries Research Board of Canada 32(10): 1767-1775.

43. Hakanson L (1980) An ecological risk index for aquatic pollution control. A sedimentological approach. Water research 14(8): 9751001.
44. Yang Z, Wang Y, Shen Z, Niu J, Tang Z (2009) Distribution and speciation of heavy metals from the mainstream, tributaries, and lakes of the Yangtz River catchment of Wuhan, China. Journal of Hazardous Materials 166(2-3): 1186-1194.

45. Chakravarty M, Patgiri AD (2009) Metal pollution assessment in sediments of the Dikrong River, NE India. Journal of human ecology 27(1): 63-67.

46. Seshan B, Natesan U, Deepthi K (2010) Geochemical and statistical approach for evaluation of heavy metal pollution in core sediments in southeast coast of India. International Journal of Environmental Science and Technology 7(2): 291-306.

47. Qui H (2010) Studies on the potential ecological risk and homology correlation of heavy metal in the surface soil. Journal of Animal Science 2(2): 194-201.

48. Wang S, Shi X (2001) Molecular mechanisms of metal toxicity and carcinogenesis. Molecular and Cellular Biochemistry 222(1-2): 3-9.

49. Kasprzak KS (2002) Oxidative DNA and protein damage in metalinduced toxicity and carcinogenesis. Free Radical Biology and Medicine 32(10): 958-967.

50. Beyersmann D, Hartwig A (2008) Carcinogenic metal compounds: recent insight into molecular and cellular mechanisms. Archives of toxicology 82(8): 493-512.

51. Tchounwou PB, Centeno JA, Patlolla AK (2004a) Arsenic toxicity, mutagenesis and carcinogenesis - a health risk assessment and management approach. Mol Cell Biochem 255(1-2): 47-55.

52. Yedjou CG, Tchounwou PB (2006) Oxidative stress in human leukemia cells (HL-60), human livercarcinoma cells (HepG2) and human Jerkat-T cells exposed to arsenic trioxide. Metal Ions in Biology and Medicine 9: 298-303.

53. Tchounwou PB, Ishaque AB, Schneider J (2001) Cytotoxicity and transcriptional activation of stress genes in human liver carcinoma cells (HepG2) exposed to cadmium chloride. Molecular and Cellular Biochemistry 222(1-2): 21-28.

54. Patlolla A, Barnes C, Yedjou C, Velma V, Tchounwou PB (2009b) Oxidative stress, DNA damage and antioxidant enzyme activity induced by hexavalent chromium in Sprague Dawley rats. Environmental toxicology 24(1): 66-73.

55. Tchounwou PB, Yedjou CG, Foxx D, Ishaque A, Shen E (2004b) Leadinduced cytotoxicity and transcriptional activation of stress genes in human liver carcinoma cells (HepG2). Molecular and cellular biochemistry 255(1-2): 161-170.

56. Sutton DJ, Tchounwou PB (2007) Mercury induces the externalization of phosphatidylserine in human proximal tubule (HK-2) cells. Int J Environ Res Public Health 4(2): 138-144.

57. Hamer DH (1986) Metallothioneins. Annual Review of Biochemistry 55: 913-951.

58. ASTM (1990) Standard Guide for Conducting Life-cycle Toxicity Tests with Saltwater Mysids, E1191. In ASTM Annual Book. ASTM Publs. Philadelphia pp.736-751. 
59. Widdows J (1998) Marine and estuarine invertebrate toxicity tests In: Calow P (ED.). The Handbook of Ecotoxicology. Blackwell Science, Oxford, pp. 145-166.

60. Magos L, Webb M (1980) The interactions of selenium with cadmium and mercury. CRC Critical Reviews in Toxicology 8(1): 1-2.

61. Norheim G (1987) Levels and interactions of heavy metals in seabirds from Svalbard and the Antarctic. Environmental Pollution 47: 83-94.

62. Davis JM, Russel R (1988) The influence of dissolved selenium compounds on the accumulation of inorganic and methylated mercury compounds from solution by the mussel Mytilus edulis and the plaice Pleuronectes platessa. Science of the total environment 68: 197-205.

63. Sunda WG, Huntsman SA (1983) Effect of competitive interactions between manganese and copper on cellular manganese and growth in estuarine and oceanic species of the diatom Thalassiosira. Limnology and Oceanography 28: 924-934.

64. Kangwe JW (1999) The effects of land-based pollution on reef building calcareous algae in the reefs near Zanzibar town. University of Dares Salaam, Tanzania, p. 97.
65. Khaled A, El Nemr A, El Sikaily A, El Sarraf WM (2010) Assessment of heavy metals in the sediments of the Mediterranean coast of Egypt. Egyptian Journal of Aquatic Research 36: 43-53.

66. Khallaf EA, Galal M, Authman M (1995) A study of the seasonal variation of pesticides contamination in Nile drainage canal water, and their subsequent occurrence in some Oreochromis niloticus organs. In Proceedings of the Fifth International Conference, Environmental protection is a must 25: 89-120.

67. Mekkawy IAA, Mahmoud M, Ibrahim ATA (2008) Heavy metal distribution and their corresponding damage effect in some organs of Bagrus bajad (Forsskal, 1775) from three localities at Assiut, Egypt. Egyptian German Society of Zoology 54: 119-137.

68. Ohman L, Sjoberg S (1988) Metal Speciation: Theory Analysis and Applications. Lewis Publishers, Chelsea, New York, USA, p: 1.

69. Patlolla A, Barnes C, Field J, Hackett D, Tchounwou PB (2009a) Potassium dichromate-induced cytotoxicity, genotoxicity and oxidative stress in human liver carcinoma (HepG2) cells. International Journal of Environmental Research and Public Health 6(2): 643-653.

\section{Your next submission with Juniper Publishers will reach you the below assets}

- Quality Editorial service

- Swift Peer Review

- Reprints availability

- E-prints Service

- Manuscript Podcast for convenient understanding

- Global attainment for your research

- Manuscript accessibility in different formats ( Pdf, E-pub, Full Text, Audio)

- Unceasing customer service

Track the below URL for one-step submission https://juniperpublishers.com/online-submission.php 